\title{
Species richness and distribution of benthic tidal flat fauna of the Banc d'Arguin, Mauritania
}

\author{
Gerard WIJNSMA ${ }^{a}$, Wim J. WOLFF ${ }^{a *}$, André MEIJBOOM ${ }^{b}$, Piet DUIVEN ${ }^{c}$, Jaap DE VLAS ${ }^{d}$ \\ ${ }^{a}$ Groningen University, Dept. of Marine Biology, P.O. Box 14, NL 9750 AA, Haren, The Netherlands \\ ${ }^{b}$ Institute for Forestry and Nature Research, P.O. Box 167, NL 1790 AD, Den Burg, Texel, The Netherlands \\ ${ }^{c}$ Netherlands Institute for Sea Research, P.O. Box 59, NL 1790 AB, Den Burg, Texel, The Netherlands \\ ${ }^{d}$ Ministry of Agriculture, Nature Management and Fisheries, Directorate Noord, Groningen, The Netherlands
}

(Received 7 May 1998, revised 2 October 1998, accepted 21 October 1998)

\begin{abstract}
The Banc d'Arguin in Mauritania, West Africa, is an area of tidal flats and shallow inshore waters bordering the sandy desert of the Sahara. The project Banc d'Arguin 1985-1986 investigated predominantly benthic biomass and production, the same data allow investigation of the species diversity and the distribution of the tidal flat fauna of the Banc d'Arguin. We sieved and analysed 410 core samples (diameter $10 \mathrm{~cm}$ ) from 82 locations with $0.6 \mathrm{~mm}$ mesh size. A total of 111 taxa were identified. Polychaeta were most diverse with 42 species belonging to 20 families. Other large species groups were Gastropoda (20 species, 14 families), Amphipoda (14 taxa, 8 families) and Bivalvia (15 species, 10 families). Densities ranged from 152 to 5635 ind. $\mathrm{m}^{-2}$, with an average of $1404 \mathrm{ind} . \mathrm{m}^{-2}$. Six taxa accounted for more than half of the total density, $\mathrm{H}^{\prime}$ values were generally low with values ranging from 0 to 2.78 nats. Low evenness values indicated a high degree of dominance.

The total density was independent of any sediment characteristic, probably because of the large range of species. Densities of dominant species did show a correlation with sediment size. A fraction of the individuals could have been lost with our use of a $0.6 \mathrm{~mm}$ sieve. Many species occurred only at a few stations. An explanation for this could be that stations are dominated by different species, while the diversity within a station is relatively low. The occurrence of opportunistic species supports this explanation. The Banc d'Arguin is a reversed estuary, and the stress caused by high temperatures and salinity could result in opportunistic assemblages. The (theoretical) high turnover rate of these opportunistic assemblages could be the key to the importance of the Banc d'Arguin for wintering shorebirds. $\mathbb{C}$ Elsevier, Paris / Ifremer / Cnrs / Ird
\end{abstract}

\section{Banc d'Arguin / benthos / diversity / shorebirds}

Résumé - Richesse spécifique et répartition de la faune benthique du Banc d'Arguin, Mauritanie. Le Banc d'Arguin, à l'ouest de l'Afrique, est une région de vasières et d'eaux littorales peu profondes en bordure des sables désertiques du Sahara. Le programme Banc d'Arguin 1985-1986 avait pour thème la biomasse benthique et la production, la diversité spécifique et la répartition de la faune dans la zone des marées du Banc d'Arguin. Des prélèvements, au nombre de 410 (diamètre $10 \mathrm{~cm}$ ) ont été effectués en 82 stations, filtrés (maille $0,6 \mathrm{~mm}$ ) puis analysés. Au total, 111 taxons ont été identifiés. Les polychètes présentent la plus grande diversité avec 42 espèces appartenant à 20 familles. Viennent ensuite les gastropodes ( 20 espèces, 14 familles), les amphipodes (14 taxons, 8 familles) et les bivalves ( 15 espèces, 10 familles). La gammc des densités s'étend de 152 à 5635 individus par mètre carré, avec une moyenne de 1404 individus par mètre carré. Plus de la moitié de cette densité est due à six taxons. Les valeurs de $\mathrm{H}$, sont généralement faibles, de zéro à 2,78 nats. La faible régularité traduit un fort degré de dominance. La densité totale n'est liée à aucune caractéristique du sédiment, probablement en raison du grand nombre d'espèces. Les densités des espèces dominantes sont corrélées à la granulométrie du sédiment. Une partie des individus a probablement été perdue dans la filtration sur maille de $0,6 \mathrm{~mm}$. Plusieurs espèces apparaissent seulement en quelques stations, peut-être parce que les stations sont dominées par des espèces différentes et la

* Correspondence and reprints: Prof. Wim J. Wolff: W.J.Wolff@biol.rug.nl 
diversité est relativement faible en une même station. La présence d'espèces opportunistes confirme cette hypothèse. Le Banc d'Arguin est un estuaire renversé où les contraintes de température et salinité expliqueraient la présence des populations opportunistes. La valeur théorique élevée du taux de renouvellement de ces populations opportunistes pourrait expliquer l'importance du Banc d'Arguin dans l'hivernage des oiseaux côtiers. () Elsevier, Paris / Ifremer / Cnrs / Ird

\section{Banc d'Arguin / benthos / diversité / limicole}

\section{INTRODUCTION}

The Banc d'Arguin in Mauritania, West Africa, is an area of tidal flats and shallow inshore waters bordcring the sandy desert of the Sahara (figure 1). Since 1976 about $12000 \mathrm{~km}^{2}$ of shallow water, tidal flats, and adjacent desert have been included in the Parc National du Banc d'Arguin. Ornithological studies have shown that the Banc d'Arguin is the most important wintering site for shorebirds migrating along the eastern shores of the Atlantic [19].

Altenburg et al. [4] collected some data on the benthic macrofauna of the tidal flats, being the food of the wintering waders. They found, contrary to expectation, that the benthic biomass at the tidal flats of the Banc d'Arguin in February 1980 amounted to $7.6 \mathrm{~g} \mathrm{~m}^{-2}$ of ash-free dry mass (AFDM) only. Hence, over two million waders appeared to be dependent on a relatively small benthic biomass occurring in a relatively small tidal flat area of just over $500 \mathrm{~km}^{2}$. Compared to NW European estuaries, the Banc d'Arguin seems to be very poor in food relative to its large numbers of birds [32].

The project Banc d'Arguin 1985-1986 was carried out to investigate this peculiar situation in more detail. A detailed report on the ornithological research was carried out in 1985-1986 by Ens et al. [10]. The data on benthic biomass and production have been reported by Wolff et al. $[29,28]$. The same data, however, allow investigation of the species diversity and the distribution of the tidal flat fauna of the Banc d'Arguin. This paper attempts to summarize these data.

\section{MATERIALS AND METHODS}

Geographical data were derived from the maps published by Altenburg et al. [4] and a LANDSAT- 4 MSS image recorded on 29 September 1984 . They were checked using oblique aerial full colour photographs of a part of the tidal flat area and ground truth obtained at about 130 sites chosen at random at the tidal flats in February-April

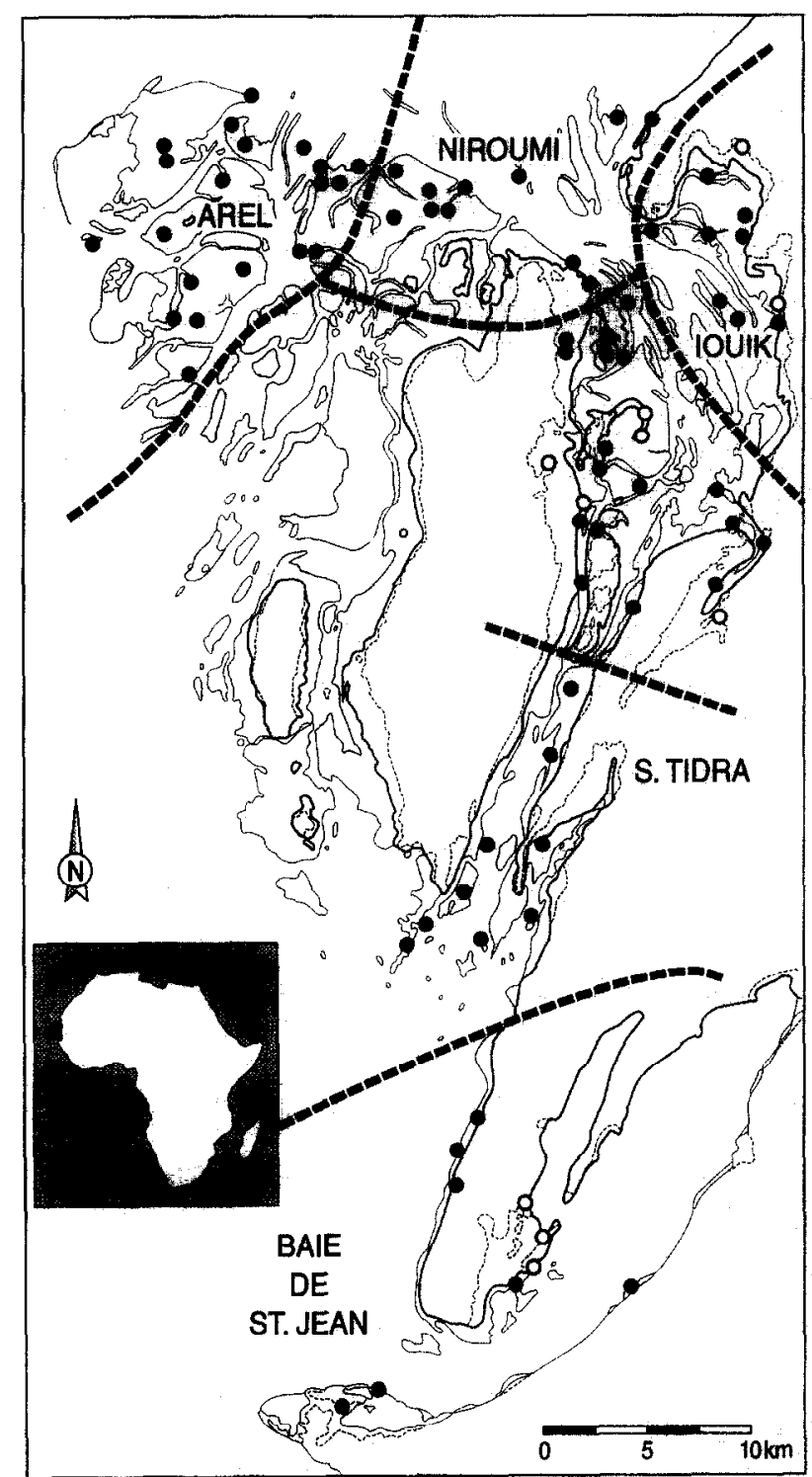

Figure 1. Location of the Banc d'Arguin (insert). Location of sample stations. The subdivision in subareas is illustrated by the dotted lines. Open symbols are sebkhas.

1986. Low tide at Iouik on 29 September 1984 occurred at 9.26 am local time; the satellite passed over this area at about 10.40 am local time. This was two days after equi- 
noctial spring tide with extremely high tide levels. The data were processed by the PIXYS Remote Sensing and Image Processing System of the Netherlands' Institute for Forestry and Nature Research at Arnhem. The data were geometrically corrected with line resampling (factor 1.404). A general map of the intertidal zone at low tide was based on functions of the red (R) and infrared (IR) reflectance. Differences in IR allowed the distinction between dry land, sebkhas (barren salt flats), sandy tidal flats, muddy tidal flats, and water. The occurrence of seagrass beds, marshes, and mangroves has been mapped using a vegetation index (VI) calculated as $\mathrm{VI}=\arctan$ (IR/R) which ranges from 0 (IR $=0 ; R>0)$ to 90 (IR >0; $R=0$ ). The same data have been used to compute the areas (number * size of pixels) of the various types of habitats distinguished.

The sampling stations have been chosen at random. On a 1:170000 map of the tidal flat area based on satellite imagery arbitrary horizontal and vertical co-ordinates were drawn at distances of $1 \mathrm{~mm}$. Sampling stations were determined by choosing co-ordinates from a table of random numbers. Over 200 stations were thus selected, but in practice only 82 stations were sampled (figure 1 ). The remainder either appeared not to be situated in the intertidal zone, or were difficult to visit due to restrictions on transportation by the authorities of the Parc National du Banc d'Arguin. The stations sampled cover the subareas investigated completely, no stations in these areas have been omitted. Our subareas differ slightly from those used in Wolff et al. [28] but are geographically more straightforward (figure I).

Nearly all the stations sampled were visited by boat. Navigating on landmarks and the topography of the tidal flats, the stations were approached as close as possible. Before the boat was left the number of paces to the station was estimated and this distance was walked over the flats. At the sampling station the very large bivalve Anadara senilis was sampled by hand using ranked sets sampling by means of $0.25 \mathrm{~m}^{2}$ quadrates [29]. When A. senilis did occur in the core samples it was neglected. All other species were sampled with a corer of $10 \mathrm{~cm}$ internal diameter which was pushed into the sediment to a depth of about $40-45 \mathrm{~cm}$. At each station five core samples were randomly taken. The cores were sieved through a sieve with a mesh width of $0.6 \mathrm{~mm}$ (except for the samples from two stations with coarse sediment: $1 \mathrm{~mm}$ ) and put into polythene bags. All samples were sorted while still alive in our 'laboratory' tent. All species were preserved in seawater with about $5 \%$ buffered formalin. Identification was carried out at the laboratory of the Institute for Forestry and Nature Research at Texel, The Netherlands, for all taxonomic groups except for crustaceans. Species from the latter group were identified at the Institute of Taxonomic Zoology of the University of Amsterdam because of the large number of rare and undescribed species. Some large and/or very mobile species did not turn up in our core samples, for instance the decapod crustaceans Uca tangeri and Callinectes marginatus, and the gastropod molluscs Cymbium cymbium, Conus pulcher papilionaceus, and Semifusus morio.

At each sampling station the following data were noted: geographical position, tidal level, nature of the sediment, occurrence of macrophytes, occurrence of all macrofauna species recognisable in the field, and any peculiarities. Also a sediment sample was taken and analysed in the Netherlands for grain-size distribution, organic matter content; calcium carbonate content, and $\mathrm{pH}$. Salinity and water temperatures were only determined in the main tidal channels, not at the sampling stations.

Subsamples were pooled for each station to calculate the Shannon Weaver diversity index $\left(\mathrm{H}^{\prime}\right)$ and evenness $\left(\mathrm{J}^{\prime}\right)$ using natural $\log$ as base [31]. Prior to univariate analysis of macrofauna distribution the parameters or their inverses were normalized using the log transformation. If the distribution was still irregular after transformation the Spcarman Rank correlation coefficient (SR) was used instead of the Pearson product moment correlation coefficient $(\mathrm{P})$.

The data were also subjected to cluster analysis, a multivariate statistical tool that provides an objective way to discriminate between groups of datasets [11]. Field et al. [11] adopted the Bray-Curtis measure [6], which was originally used in plant ecology, for use in marine research. We transformed the data, consisting of the numbers of individuals per taxon per station, with the double root transformation $\left[Y i j=\sqrt{ }\left(\sqrt{ }\left(X_{i j}\right)\right]\right.$ to scale down the scores of abundant species [11]. We used the Bray-Curtis measure as a dissimilarity measure, with unweighted pair-group average as linkage method, as recommended by Field et al. [11]. Species that occurred at only one or two stations were excluded from the analysis. An important disadvantage of clustering is that linkage is irreversible, so a second method to display similarities without irreversible linkage has been used [11]. The additional method used is nonmetric Multi Dimensional Scaling (MDS) [7, 13]. The values of the dimensions in MDS were checked for correlation with habitat and fauna 
parameters. For all our calculations we used the Statistica package [23] in combination with Microsoft Excel.

\section{ABIOTIC CONDITIONS AT THE BANC D'ARGUIN}

\subsection{Hydrography}

The average tidal amplitude at louik over 3.5 spring and neap tide cycles (18 February-10 April 1986) amounts to $1.61 \mathrm{~m}$. During spring tides the tidal amplitude is approximately $2 \mathrm{~m}(1.85-2.15 \mathrm{~m}$ was recorded during four spring tide periods), during neap tides about $1 \mathrm{~m}(0.80$ $1.40 \mathrm{~m}$, records during five neap tide periods) $[20,30]$. The equinoctial spring tides in March 1985 and 1986 were not particularly extreme, but the equinoctial spring tide with an estimated amplitude of $2.67 \mathrm{~m}$ on 28 August 1988 was the largest we have observed (Ens, Klaassen and Wolff, unpubl. data). During the latter tide as well as the slightly less extreme spring tide two weeks later the larger part of the sebkhas was inundated during flood, a phenomenon we did not observe in spring.

Offshore water enters the shallows of the Banc d'Arguin between Cap Blanc and Cap St. Anne [15]. After this the ocean water is transported to the south to arrive at the tidal flat area southwest of Cap Tafarit, from where it returns through a number of channels to the open ocean. During the transport over the tidal flats water temperature and salinity increase due to the strong insolation and evaporation [15]. Water temperatures in the channels increase gradually from $19^{\circ} \mathrm{C}$ in February to approximately $21^{\circ} \mathrm{C}$ in April, but insolation during low tide can give much higher temperatures in the sediment. Salinity values in April range from 35-36 in open sea to 38 around Arel to about 40 closer to shore. In landlocked bays extreme salinities can sometimes be found of up to 81.6 in the Baie de St Jean [15, 20]. Hence, a temperature and salinity gradient exists from open sea to the coast, with hypersaline conditions in land-locked bays. Wolff and Smit [30] present a more detailed overview of the hydrography of the Banc d'Arguin.

\subsection{Meteorology}

Adjacent to the Sahara desert, mean air temperatures at the Banc d'Arguin range from $20-30^{\circ} \mathrm{C}$. Winds are mostly from northern directions with moderate force (4-5 Beaufort). At night temperatures can be lower, around $15^{\circ} \mathrm{C}$. A rapid increase in temperature can occur when wind blows from the Sahara [21]. Precipitation during our stay in 1985 and 1986 was negligible with 0.2 and 0.1 mm, respectively. However, thunderstorns occur at irregular intervals, sometimes several years apart. In September and October 1988 we measured $24 \mathrm{~mm}$ as the result of five thunderstorms (Klaassen and Zwarts, unpubl. data). More detailed information on the meteorology of the Banc d'Arguin is given by Smit et al. [21] and Wolff and Smit [30l.

\subsection{Soils and sediments}

The larger part of the Banc d'Arguin area consists of soft sediments. Only locally rocky outcrops occur, predominantly at and in the vicinity of capes and headlands. Scattered over the tidal flats concentrations of stones occur, but the area covered by these is very small. At the tidal flats sandy and muddy areas alternate. In general the areas covered with seagrass are muddy, whereas unvegetated areas are sandy. Sandy areas occur especially in places where the tidal currents enter and leave large tidal flat areas. Also at the highest tidal levels, where due to a large fetch of the wind at high tide, larger waves reach the shore, sandy areas are found. The sebkhas, situated above high tide level, are in general sandy, as are the adjacent parts of the desert. Table I in Wolff et al. [28] shows some characteristics of the sediment in different habitats.

Table I. Densities of the main taxa at the Banc d'Arguin. Data are derived from Table III in Wolff et al. [28].

\begin{tabular}{|c|c|c|c|}
\hline Taxon: & \multicolumn{3}{|c|}{ Density (individuals $\mathbf{m}^{-2}$ ) } \\
\hline Bivalvia & & 173.4 & \\
\hline Gastropoda & & 215.7 & \\
\hline total Mollusca & & & 389.5 \\
\hline Insecta & & 1.4 & \\
\hline Amphipoda & 47.0 & & \\
\hline Isopoda & 78.9 & & \\
\hline Tanaidacea & 3.2 & & \\
\hline total Crustacea & & 145.0 & \\
\hline total Arthropoda & & & 146.4 \\
\hline Echinodermata & & & 21.6 \\
\hline Polychaeta & & 788.7 & \\
\hline Oligochaeta & & 44.6 & \\
\hline total Annelida & & & 833.3 \\
\hline Sipunculida & & & 11.7 \\
\hline Turbellaria & & & 1.1 \\
\hline Coelenterata & & & 1.4 \\
\hline Total & & & 1404.6 \\
\hline
\end{tabular}




\subsection{Tidal flat area}

Wolff and Smit [30] calculated that the tidal flat area of the Banc d'Arguin covers about $425 \mathrm{~km}^{2}$ between Cap Tafarit and Cap Timiris and about $66 \mathrm{~km}^{2}$ in the Baie d'Arguin (table II in [30]). This is about $100 \mathrm{~km}^{2}$ less than recorded by Altenburg et al. [4]. This difference is mainly caused by a different evaluation of the situation in the Baie de St. Jean. Wolff and Smit [30] found nearly exclusively subtidal flats whereas Altenburg et al. [4] recorded vast areas of intertidal flats.

\section{RESULTS}

\subsection{Benthic fauna}

Of the 82 stations sampled, 10 could be characterized as sebkhas, salt flats mostly situated above high tide level. No marine animals were encountered there, therefore these stations are excluded from our further analysis. From our samples and in the field we identified a total of 111 taxa. Some specimens could not be identified to species level, but were identified as far as possible. Table III in Wolff et al. [28] lists all taxa with their average density, biomass and frequencies of occurrence in our samples. Polychaeta were the most diverse higher taxon with 42 species belonging to 20 families. Other large species groups were Gastropoda (20 species, 14 families), Amphipoda (14 taxa, 8 families) and Bivalvia (15 species, 10 families). Densities per station ranged from 152 to 5635 ind. $\mathrm{m}^{-2}$, with an average of 1405 ind. $\mathrm{m}^{-2}$. Polychaeta and Mollusca accounted for most individuals, notably Capitella capitata. Six taxa, the polychaetes C. capitata, Euclymene oerstedii and Naineris laevigata, the bivalve Loripes lacteus, the gastropod Hydrobia ulvae and the isopod family Anthuridae accounted for more than half of the total density. Table I displays the densities of the major taxa at the Banc d'Arguin.

Table II. Average densities, diversity (H', Shannon Weaver index and J', Evenness) and average numbers of species of the subareas of the Banc d'Arguin.

\begin{tabular}{lcccccc}
\hline & $\begin{array}{c}\text { Subsamples } \\
\text { (n) }\end{array}$ & $\begin{array}{c}\text { Density } \\
\text { (ind } \mathbf{~ m}^{\mathbf{2}} \text { ) }\end{array}$ & $\begin{array}{c}\text { Number } \\
\text { of species }\end{array}$ & $\begin{array}{c}\text { Species } \\
\text { per station }\end{array}$ & H' & J' \\
\hline Arel & 100 & 1073.3 & 69 & 12.7 & 1.99 & 0.83 \\
Iouik & 40 & 1082.3 & 42 & 10.9 & 1.82 & 0.81 \\
Niroumi & 55 & 1944.6 & 66 & 13.3 & 1.83 & 0.71 \\
North Tidra & 85 & 1400.6 & 61 & 11.4 & 1.76 & 0.77 \\
Baie de St Jean & 35 & 2015.4 & 30 & 7.9 & 1.14 & 0.45 \\
South Tidra & 45 & 1253.4 & 50 & 11.6 & 1.85 & 0.77 \\
\hline
\end{tabular}

Table III. Summary of habitat and faunal parameters of the stations in the clusters identified in figure 2. Original data codes for tidal level are 0 for low, 1 for medium, 2 for high level. Significant differences are indicated as follows; each pair of superscript characters (small and capital) denotes a significant difference (MANOVA; $\mathrm{p}<0.05$ ).

\begin{tabular}{|c|c|c|c|c|c|c|c|c|}
\hline Cluster & $\begin{array}{l}\text { Seagrass } \\
\text { cover }\end{array}$ & $\begin{array}{l}\text { Tidal } \\
\text { level }\end{array}$ & $\begin{array}{l}\text { Density } \\
\text { (ind } \mathrm{m}^{-2} \text { ) }\end{array}$ & $\begin{array}{l}\text { Number } \\
\text { of species } \\
\text { per station }\end{array}$ & $\mathbf{J}^{\prime}$ & $\mathbf{H}^{\prime}$ & $\begin{array}{l}\text { Organic } \\
\text { content }(\%)\end{array}$ & $\begin{array}{l}\text { Grain size } \\
<16 \mu \mathrm{m}(\%)\end{array}$ \\
\hline 1 & variable & 1.33 & $356.5^{\mathrm{a}}$ & $1.3^{\mathrm{a}}$ & $0.27^{A}$ & $0.72^{\mathrm{a}}$ & $1.50^{\mathrm{a}}$ & $3.23^{\mathrm{a}}$ \\
\hline 2 & variable & 1.33 & $1088.6^{\mathrm{a}}$ & $7.8^{\mathrm{Ab}}$ & $0.65^{\mathrm{a}}$ & $1.62^{\mathrm{A}}$ & 4.07 & $17.23^{\mathrm{AbH}}$ \\
\hline 3 & yes & 1.00 & $267.4^{\mathrm{a}}$ & $4.0^{c}$ & $0.79^{a}$ & $1.09^{\mathrm{ab}}$ & $2.15^{\mathrm{b}}$ & $7.20^{c}$ \\
\hline 4 & no (most) & 1.80 & $3765.2^{A}$ & $10.1^{\mathrm{ACd}}$ & $0.72^{\mathrm{a}}$ & $1.76^{\mathrm{A}}$ & $1.60^{\mathrm{a}}$ & $8.55^{d}$ \\
\hline 5 & yes & 0.00 & $814.9^{a}$ & $10.0^{\mathrm{Ae}}$ & $0.75^{\mathrm{a}}$ & $1.73^{\mathrm{A}}$ & $7.20^{\mathrm{ABcE}}$ & $17.95^{\mathrm{ACDeHi}}$ \\
\hline 6 & yes & 0.25 & $1288.5^{\mathrm{a}}$ & $15.0^{\mathrm{ABCDf}}$ & $0.85^{\mathrm{a}}$ & $2.39^{\mathrm{ABC}}$ & $6.64^{\mathrm{ABE}}$ & $15.38^{\mathrm{ACDfHi}}$ \\
\hline 7 & yes & 0.67 & $1420.9^{a}$ & $15.3^{\mathrm{ABCDg}}$ & $0.79^{\mathrm{a}}$ & $2.08^{\mathrm{AB}}$ & $4.60^{\mathrm{AdE}}$ & $16.78^{\mathrm{ADEgHi}}$ \\
\hline 8 & variable & 0.00 & $814.9^{\mathrm{a}}$ & $11.7^{\mathrm{ABCh}}$ & $0.86^{\mathrm{a}}$ & $1.66^{\mathrm{A}}$ & $0.93^{\mathrm{CDe}}$ & $3.27^{\mathrm{BEFGhJ}}$ \\
\hline 9 & yes & 0.50 & $1502.4^{a}$ & $15.0^{\mathrm{ABCi}}$ & $0.67^{\mathrm{a}}$ & $1.44^{\mathrm{A}}$ & $0.80^{\mathrm{Ce}}$ & $2.55^{\text {BEFGhJ }}$ \\
\hline 10 & variable & 0.67 & $744.9^{\mathrm{ab}}$ & $10.5^{\mathrm{ACFGj}}$ & $0.79^{\mathrm{a}}$ & $1.86^{\mathrm{A}}$ & $1.90^{\mathrm{CDe}}$ & $7.30^{\text {EFGiJ }}$ \\
\hline 11 & yes(most) & 0.71 & $2037.2^{\mathrm{aB}}$ & $17.8^{\mathrm{ABCDEHJK}}$ & $0.82^{\mathrm{a}}$ & $2.18^{\mathrm{AB}}$ & $1.56^{\mathrm{CDe}}$ & $6.06^{\mathrm{EFGiJ}}$ \\
\hline 12 & yes & 0.25 & $619.6^{\mathrm{ab}}$ & $8.5^{\text {AFGIK }}$ & $0.74^{\mathrm{a}}$ & $1.59^{\mathrm{Ac}}$ & $2.75^{\mathrm{C}}$ & $11.43^{\mathrm{cEF}}$ \\
\hline 13 & yes & 0.50 & $1706.1^{\mathrm{a}}$ & $13.8^{\mathrm{ABCk}}$ & $0.77^{\mathrm{a}}$ & $1.82^{\mathrm{A}}$ & $6.05^{\mathrm{ABE}}$ & $22.55^{\mathrm{ACDHij}}$ \\
\hline
\end{tabular}


In table /I the diversity of each subarea is summarized along with the average macrofauna density. Numbers of species per subarea ranged from 30 species in the Baie de St Jean to 69 species in Arel. Average numbers of species per station found per subarca ranged from 7.9 to 13.3, whereas the actual numbers per station ranged from 1 to 25. Average $\mathrm{H}^{\prime}$ values per station per subarea ranged from, 1.14 to 1.99 nats, whereas the actual values per station ranged from 0 to 2.78 nats, with an average of 1.79 nats. Evenness per subarea ranged from 0.45 to 0.83 , whereas the values per station ranged from 0 to 0.97 with an average of 0.75 . The Baie de St Jean has the most dense and least diverse fauna of all subareas. Nine species account for $90 \%$ of the individuals sampled in the Baie de St Jean. Niroumi has approximately the same density but has a more diverse fauna, 26 species account for $90 \%$ of the individuals. Individual stations with low diversity occurred throughout the area and were not lim- ited to certain subareas, although there seemed to be a general trend for stations with a lower diversity to appear in landinward regions.

Figure 2 displays the results of the clustcr analysis. Linc A shows the distance at which clusters were separated; the 13 clusters separated are named in Arabic numerals from left to right. The clusters consist of up to ten stations. Clusters were evenly distributed over subareas and differed rather in habitat and fauna parameters. An overview of these parameters is given in table III. Density of macrofauna differed significantly only between cluster 4 and the other clusters and between cluster pairs 10, 11 and 11, 12 (MANOVA, $p<0.05$ ). Evenness of cluster 1 was the only one to differ significantly from the rest $(p<0.01$ except with clu9 $p<0.05)$. The other quantitative parameters differed significantly on most occasions, except when the number of stations within a cluster or the

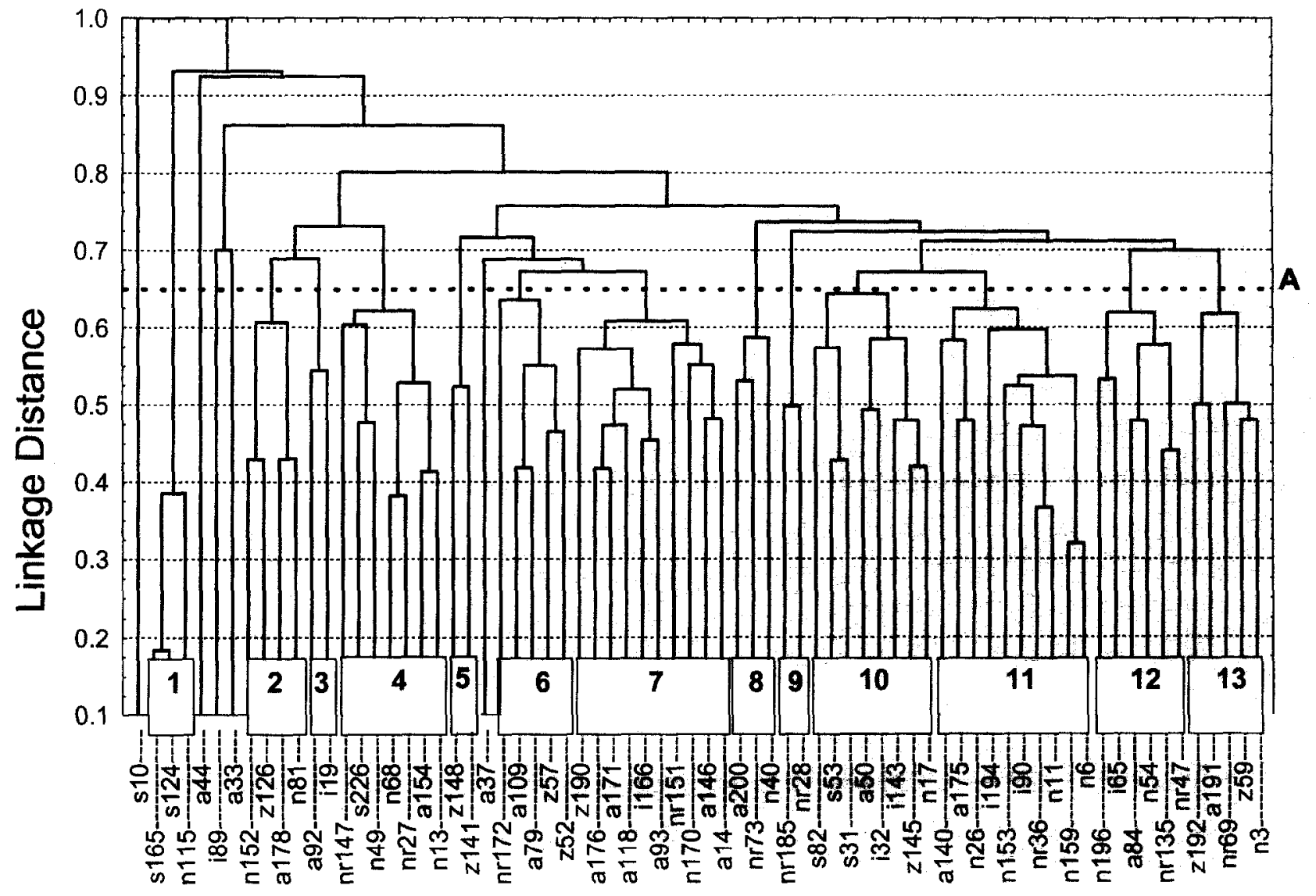

Figure 2. Dendrogram of cluster analysis using a matrix excluding species that occur in two or less stations. Line A shows where the clusters are separated. Station names combine station numbers (figure l) with subarea: a: Arel; i: Iouik; n: North Tidra; nr: Niroumi; s: Baie de St Jean and $\mathrm{z}$ : South Tidra. Arabic numerals denote the clusters as discussed in the text. 


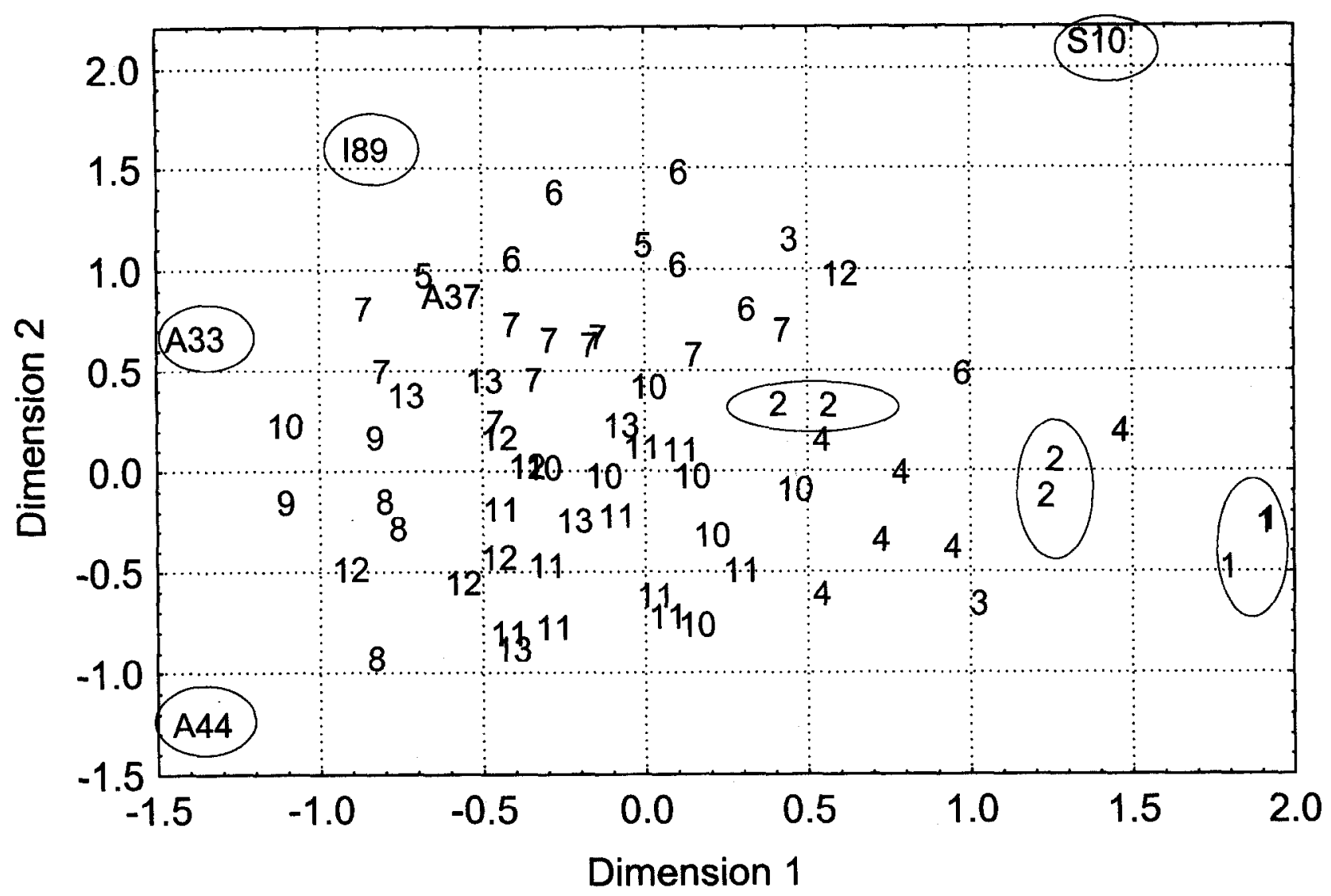

Figure 3. MDS ordination in two dimensions. Numerals denote the stations of the clusters from figure 2, single station clusters are represented by their station number. Encircled clusters are discussed in the text.

differences between clusters were very small $(p<0.01$ or 0.05 ). A MANOVA was used because of the unequal intercorrelation between the parameters, which could result in unequal variances [31].

A plot of number of MDS dimensions against stress, indicated that probably two but not more than three dimensions should be used [13]. The results of MDS in two dimensions are shown in figure 3, the numbers represent the clusters of figure 2 . Single station-clusters are represented by their station name. Stress is 0.2702 . Parameters that are significantly correlated with MDS-dimensions are displayed in table IV.

\subsection{Benthic habitats}

Extensive areas of the tidal flats are covered with seagrass. We estimate that at least $196 \mathrm{~km}^{2}$ of the tidal flats
Table IV. Correlations of habitat and fauna parameters with the dimensions calculated in MDS. Displayed is the Pearson product moment correlation coefficient (Spearman rank correlation for seagrass cover and tidal level). Transformation necessary for normalization of variables prior to Pearson correlation is indicated. Significance is indicated by $*$ for $\mathrm{p}<0.05, * *$ for $\mathrm{p}<0.01, * * *$ for $\mathrm{p}<0.001$. Blank cells denote non-significant correlations. Original data codes for seagrass cover are 0 for no seagrass, 1 low to medium coverage, 2 fully covered with seagrass. For tidal level codes see table III.

\begin{tabular}{lccc}
\hline & $\begin{array}{c}\text { Transfor- } \\
\text { mation }\end{array}$ & Dimension 1 & Dimension 2 \\
\hline Fraction 0-16 $\mu \mathrm{m}(\%)$ & $\log$ & & $0.33^{* *}$ \\
Organic content (\%) & $\log$ & & $0.43^{* * *}$ \\
Number of species & none & $-0.33^{* * *}$ & \\
H' $^{\prime}$ & none & $-0.57^{* * *}$ & \\
J' & $\log (1-\mathrm{x})$ & $0.59^{* * *}$ & \\
Seagrass cover & none & $-0.38^{* *}$ & $0.36^{* *}$ \\
Tidal level & none & $0.52^{* * *}$ & \\
\hline
\end{tabular}


south of Cap St. Anne are covered by seagrass beds $[28$, 30]. Three species were observed in 1985 and 1986, viz. Zostera noltii, Halodule wrightii, and Cymodocea nodosa. Of these $Z$. noltii is by far the most common species at the tidal flats. Especially on the more seaward flats where it forms a dense monospecific cover. $H$. wrightii occurs more sporadically, but in some places it is the only species present. C. nodosa is largely restricted to places covered with water at all times. Such places are pools and small creeks at the flats, the larger tidal channels in between the flats and the sublittoral areas of the Banc d'Arguin. Most tidal flats covered with seagrass beds are interspersed with 5 to $25 \mathrm{~m}$ wide pools with a depth between 0.2 and $1.0 \mathrm{~m}$.

In some places, especially near the islands of Nair and Niroumi, the cord grass Spartina maritima occurs in extensive monospecific vegetations or mixed with $Z$. noltii at the tidal flats. The $S$. maritima beds cover perhaps $25 \mathrm{~km}^{2}$ at the Banc d'Arguin. Vegetations of stunted mangroves (Avicennia africana) occur near Cap Timiris and at the northern tip of the island of Tidra covering approximately $5 \mathrm{~km}^{2}$. Benthic macro-algae occur also on the tidal flats, but were never observed to be dominant. On sandy flats a brown colouring, most likely due to benthic diatoms, was observed.

\section{DISCUSSION}

The number of species encountered in our samples is in the same range as numbers of species encountered in other tropical tidal flat areas, although the number of species encountered elsewhere is highly variable. The approximate range is from 30 to 200 species $[2,8,14,25$, 26]. The high number of species can be partly explained by the occurrence of a variety of habitats, differing in sediment, salinity or seagrass-coverage, each habitat occupied by different species. This has been described in other systems [12]. Our values for H' indicate a moderately high diversity in the area. Because $H^{\prime}$ values depend on the sample regime and the log-base used, a comparison with other studies is often inappropriate [27]. Although the Banc d'Arguin is rich in species these species are unevenly distributed, over a third of the species (35) occurred only in one or two subsamples. This apparent contradiction can be explained by a dominance of each station by different species, resulting in a diverse outlook for the entire (sub)area.

In our samples, opportunistic species (Capitella capitata; Heteromastus filiformis; Naineris laevigata) occur locally in high densities. Although opportunistic species do not reach high densities in all subareas, they do occur in all subareas. A single station in a subarea might have circumstances ideally suited for opportunistic species, resulting in a relatively high overall density in that area. This is enhanced by the small size and high densities typical of opportunistic species. Poor nutritional value of mangrove or seagrass litter and physical disturbance may contribute in retaining pioneering assemblages [3]. The occurrence of opportunistic infauna in this study refers to an environment with a considerable amount of stress or disturbance, where 'pollution-indicator' species can also occur [9].

The clusters from our analysis are heterogeneously distributed over the subareas. Although the clusters differed significantly on most occasions when considering diversity and sediment features, they did not consist of stations with only a certain sediment type or vegetation (table III), but were very variable. An additional problem is that in cluster analysis clusters are linked irreversibly, so dendrograms tend to overemphasize discontinuities and may force a graded series into distinct classes [11]. This makes cluster analysis unable to identify clear patterns in distribution. The distance at which clusters are separated in our analysis is quite high, which also indicates that the stations within these clusters are not very similar.

In the MDS ordination only a few outlying stations and clusters (circled in figure 3 ) were clearly separated from the rest of the stations. The rest of the stations appear close together in the centre of the ordination. The stations of the clusters are more or less grouped, but there is considerable variation. The high stress value and the scree plot indicate that a three-dimensional MDS might have given better results [7, 13]. This plot resulted, however, in similar ordinations as the 2D MDS, so these results are not displayed. The combination of multivariate tools used in this study was unable to identify clear distinctions between groups of stations, except for cluster 1 and the single station clusters. This is contra intuitive to the observation that there are large variations between stations. However, for grouping some stations need to be more similar, and thus the lack of grouping indicates that there is indeed a considerable variation between these stations.

Although the dimensions calculated in the MDS are arbitrary, correlations to habitat characteristics and diversity can serve as an indication of which the parameters are important in the distribution of stations in this ordination and thus in the distribution of macrofauna (analogous to 
Table V. Correlations of fauna densities with habitat parameters. Indicated is the use of normalization of the parameters, the significance of the observed correlation $(*, * *, * * *$ for $\mathrm{p}<0.05,0.01$ and 0.001 , respectively) and which correlation coefficient is used. Pearson product moment correlation $(\mathrm{P})$ for normally distributed parameters (after transformation) and Spearman rank correlation (S) for the others. Blank cells denote insignificant correlations.

\begin{tabular}{|c|c|c|c|c|c|c|c|c|}
\hline & & $\begin{array}{l}\text { Median grain } \\
\text { size }(\mu \mathrm{m})\end{array}$ & pH & $\begin{array}{c}\text { Organic } \\
\text { content } \\
(\%)\end{array}$ & $\begin{array}{l}\text { Grain size } \\
<16 \mu \mathrm{m} \\
(\%)\end{array}$ & $\begin{array}{c}\text { Grain size } \\
16-2000 \mu \mathrm{m} \\
(\%)\end{array}$ & Tidal level & $\begin{array}{c}\text { Seagrass } \\
\text { cover }\end{array}$ \\
\hline Coefficient & & $\mathbf{P}$ & $\mathrm{P}$ & $\mathbf{P}$ & $\mathrm{P}$ & $\mathrm{P}$ & $S$ & $S$ \\
\hline \& transformation & & none & none & $\log$ & $\log$ & $\log (100-x)$ & none & none \\
\hline $\mathrm{H}^{\prime}$ & none & & & & & $0.27^{*}$ & $-0.38^{*}$ & $-0.38 * *$ \\
\hline$J^{\prime}$ & $\log \left(1-J^{\prime}\right)$ & & $0.27 *$ & & & $-0.28 *$ & $-0.38^{*}$ & $-0.41 * * *$ \\
\hline Anthuridae & $\log$ & $-0.35^{*}$ & & $0.39^{*}$ & $0.40^{*}$ & & & \\
\hline Capitella capitata & $\log$ & & & $-0.62 * * *$ & $-0.51 * *$ & $-0.65 * * *$ & $-0.57 *$ & $0.59 * *$ \\
\hline Euclymene oerstedii & $\log$ & $0.36^{*}$ & $0.31 *$ & $-0.68 *$ & $-0.44 * *$ & & & \\
\hline Hydrobia ulvae & $\log$ & & & $-0.68^{*}$ & & & & $0.66^{*}$ \\
\hline Loripes lacteus & $\log$ & & & $0.43^{* *}$ & $0.39 *$ & $0.35 *$ & & \\
\hline $\begin{array}{l}\text { Heteromastus } \\
\text { filiformis }\end{array}$ & $\log$ & $-0.48^{*}$ & & $0.48^{*}$ & $0.41^{*}$ & $0.44 *$ & & \\
\hline Naineris laevigata & $\log$ & & $-0.60^{* * *}$ & $0.51 * *$ & $0.56 * * *$ & $0.54 * *$ & & \\
\hline
\end{tabular}

[5] who used correspondence analysis). The low correlation coefficients in table $I V$ indicate that there is a large amount of unexplained variation. The most important variables are related to sediment and diversity.

The total density was not correlated to any sediment characteristic. Densities of dominant species (table $V$ ) did show significant correlations with sediment characteristics. The different directions of the correlations of dominant species and sediment characteristics are probably the reason why total density is not significantly correlated. Densities of Anthuridae, L. lacteus, $H$. filiformis and $N$. laevigata were positively correlated to finer sediment and organic content, while $C$. capitata and $E$. oerstedii were negatively correlated to finer sediment and organic content. For $C$. capitata this is peculiar, because $C$. capitata requires organic enriched sediment for normal reproduction [24] and is normally correlated with high silt and organic matter content [1]. However C. capitata is not limited to stations with low organic contents at the Banc d'Arguin. A possible explanation could be that the organic matter is unavailable for fauna, or poorly suited as food, although this does not explain why a species with similar ecology (H. filiformis) is positively correlated to organic content. The ecology of the other species is not well studied. Correlations of densities and the MDS dimensions agree with each other in the sense that the same parameters are deemed important.

Salinity could have a very distinct influence on species distribution, but should be measured alongside species distribution [17]. In our data, the diversity of the macro- fauna is least where the highest salinity values are likely to occur, which indicates that salinity is a contributing factor in the distribution of macrofauna at the Banc d'Arguin. More and more direct information is needed regarding the influence of salinity in determining the distribution of macrofauna at the Banc d'Arguin.

As pointed out earlier [28], the use of $0.6 \mathrm{~mm}$ sieves could imply that a fraction of the total individuals might be lost. Schlacher and Woolridge [16] found that in their samples only $55 \%$ of the individuals were retained on a $0.5 \mathrm{~mm}$ sieve. It is difficult to assess the size of the fraction that might be lost. Apart from the sieve size, the lost fraction depends also on sediment size and the size distribution of the population sampled. Since body size of encountered organisms is a poor estimate of their retention on a particular mesh size, no attempt was made to correct for a lost fraction [18]. The sieve sizes $0.5(0.6)$ and $1 \mathrm{~mm}$ are widely used in macrofauna research, making our results comparable with other studies (see [2] for a review).

It is difficult to compare our results directly with other studies. Studies of tropical estuaries are rare and generally consider those estuaries with fresh- to salt water gradients. The situation at the Banc d'Arguin is quite uncommon. Although similar reversed estuaries do occur, often more attention is given to their hydrodynamics than their faunal composition [22]. The present study can serve as a framework for other studies of the ecology of benthic infauna in reversed estuaries. The densities of the present study (152 to 5635 ind. $\mathrm{m}^{-2}$, average 1405 ind. $\mathrm{m}^{-2}$ ) are at the lower 
end of the range reported in other studies of tropical tidal flats $[14,25]$. This is consistent with the finding of a relatively low biomass on the Banc d'Arguin [28]. In our study we find that the Banc d'Arguin is dominated by opportunistic species, the (theoretical) high turnover rate of these opportunistic assemblages could be the key to the importance of the Banc d'Arguin for wintering shorebirds.

\section{Acknowledgements}

The authors thank the Mauritanian authorities, in particular the Director of the Parc National du Banc d'Arguin, Hadya Amadou Kane, for their permission to carry out the investigations in the Parc National du Banc d'Arguin. They also thank the collaborators of the Panc National, Abou Gueye, El Hassane ould Mohammed el Abd, the late Ely ould Elemine and Pierre Campredon, as well as Cheikhna ould M'Bare of the Direction de la Protection de la Nature of the Ministry of Rural Development for their cooperation in the field. The enthusiastic way in which Peter Esselink, Jan van de Kam, Gerard Moerland and Koos Zegers did their often tiring jobs was essential to the success of the project. The logistics were taken care of by Tom van Spanje, no other participant could have improved on that; he was often supported by Pierre Campredon, Guy Germain and their families. At home important jobs were done by Gerard C. Boere and Ekko Smith. The LANDSAT data were processed by R.I. Bijlsma and E.J. Van Kootwijk. Help during identification of species was received from D. Platvoet, Gesa Hartman-Schröder, G.C. Cadée, G. Eaton and C. den Hartog.

Financial support for the project Banc d'Arguin 19851986 was received from the Bachiene Foundation, the British Ornithological Union, the Commission of the European Communities, the Fund for Research for Nature Conservation (FONA), the Netherlands' Ministry of Agriculture and Fisheries, the National Geographic Society, the Society for the Protection of Nature Monuments (Natuurmonumenten), the Prince Bernhard Foundation, the Shell Internationale Research Maatschappij, and the Netherlands' State Forestry Service (Staatsbosbeheer).

ASECNA (Agence pour la sécurité de la navigation aérienne en Afrique et à Madagascar) made weather data from Nouadhibou Airport available. The Royal Netherlands Meteorological Institute, the Rijkswaterstaat (Dept. of Public Works), and the Dienst der Domeinen helped with providing essential equipment.

\section{REFERENCES}

[1] Ajao E.A., Fagade S.O., The ecology of Capitella capitata in Lagos lagoon, Nigeria. Arch. Hydrobiol. 120 (1991) 229-240.

[2] Alongi D.M., (1990) The ecology of tropical soft-bottom benthic ecosystems, Oceanogr. Mar. Biol. Ann. Rev. 28 (1990) $381-496$.

[3] Alongi D.M., Christoffersen P., Benthic infauna and organismsediment relations in a shallow, tropical coastal area: Influence of outwelled mangrove detritus and physical disturbance, Mar. Ecol. Prog. Ser. 81 (1992) 229-245.

[4] Altenburg W., Engelmoer M., Mes R., Piersma T., Wintering waders at the Banc d'Arguin, Mauritania, Report of the Netherlands Ornithological Expedition 1980, Stichting Veth tot Steun aan Waddenonderzoek, Leiden (1982) $283 \mathrm{p}$.

[5] Ambrogi R., Bedulli D., Zurlini G., Spatial and temporal patterns in structure of macrobenthic assemblages. A threeyear study in the Northern Adriatic Sea in front of the Po river delta, P.S.Z.N.I: Mar. Ecol. 11 (1990) 25-41.

[6] Bray J.R., Curtis J.T., An ordination of the upland forest communities of Southern Wisconsin, Ecol. Monogr. 27 (1957) 325-349.
[7] Clarke K.R., Non-parametric multivariate analyses of changes in community structure, Aust. J. Ecol. 18 (1993) 117-143.

[8] Dittmann S., Benthos structure on tropical tidal flats of Australia, Helgol. Meeresunters. 49 (1995) 539-551.

[9] Eagle R.A., Rees E.I.S., Indicator species-a case for caution, Mar. Pollut. Bull. 4 (1973) 25.

[10] Ens B.J., Piersma T., Wolff W.J., Zwarts L., (Eds.) Homeward bound: Problems waders face when migrating from the Banc d'Arguin, Mauritania, to their northern breeding grounds in spring, Ardea 78 (1990) 1-364.

[11] Field J.G., Clarke K.R., Warwick R.M., A practical strategy for analysing multispecies distribution patterns, Mar. Ecol. Prog. Ser. 8 (1982) 37-52.

[12] Junoy J., Viéitez J.M., Macrozoobenthic community structure in the Ría de Foz, an intertidal estuary (Galicia, northwest Spain), Mar. Biol. 107 (1990) 329-339.

[13] Kruskal J.B., Wish M., Multidimensional scaling, Beverly Hills, CA, Sage Publications (1978). 
[14] Molina-Lara O.A., Vargas-Zamora J.A., Structure of the macrobenthos in Jaltapeque estuary, El Salvador, Rev. Biol. Trop. 42 (1994) 165-174.

[15] Reyssac J., Hydrologie, phytoplancton et production primaire de la Baie de Lévrier et du Banc d'Arguin, Bull. Inst. Fr. Afrique Noire (Dakar), Ser. A, 39 (1977) 487-550.

[16] Schlacher T.A., Woolridge T.H., How sieve mesh size affects sample estimates of estuarine benthic macrofauna, J. Exp. Mar. Biol. Ecol. 201 (1996a) 159-171.

[17] Schlacher T.A., Woolridge T.H., Axial zonation patterns of subtidal macrozoobenthos in the Gamtoos estuary, South Africa, Estuaries 19 (1996b) 680-696.

[18] Schlacher T.A., Woolridge T.H., How accurately can retention of benthic macrofauna by a particualar mesh size be predicted from body-size of organisms, Hydrobiologia 323 (1996c) 149-154.

[19] Smit C.J., Piersma T., Numbers, mid-winter distribution and migration of wader populations using the East Atlantic Flyway, in: Boyd H., Pirot J-Y. (Eds.), Flyways and reserve networks for water birds, IWRB Spec. Publ. 9, Slimbridge (1989).

[20] Smit C.J., Blomert A.-M., Zwarts L., Hydrographical measurements. in: Ens B.J., Piersma T., Wolff W.J., Zwarts L. (Eds.), Report of the Dutch-Mauritanian project Banc d'Arguin 19851986, Report WIWO 25/RIN-rapport 89/6, Leersum (1989a) $16-42$.

[21] Smit C.J., Blomert A.-M., Meijboom A., Wolff W.J., Zwarts L., Meteorological measurements, in: Ens B.J., Piersma T., Wolff W.J., Zwarts L. (Eds.), Report of the Dutch-Mauritanian project Banc d'Arguin 1985-1986, Report WIWO 25/RINrapport 89/6, Leersum (1989b) 43-56.

[22] Smith S.V., Veeh H.H., Mass balance of biogeochemically active materials (carbon, nitrogen, phosphorus) in a hypersaline gulf, Estuar. Coast. Shelf Sci. 29 (1989) 195-216.
[23] StatSoft STATISTICA for Windows, Tulsa, OK. StatSoft Inc. (1995).

[24] Tsutsumi H., Population persistence of Capitella sp. (Polychaeta; Capitellidae) on a mudflat subject to environmental disturbance by organic enrichment, Mar. Ecol. Prog. Ser 63 (1990) 147-156.

[25] Vizakat L., Harkantra S.N., Parulekar A.H., Population ecology and community structure of subtidal soft sediment dwelling macro-invertebrates of Konkan, west coast of India, Indian J. Mar. Sci. 20 (1991) 40-42.

[26] Ward T.J., Hutchings P.A., Effects of trace metals on infaunal species composition in polluted intertidal and subtidal marine sediments near a lead smelter, Spencer Gulf, South Australia, Mar. Ecol. Prog. Ser. 135 (1996) 123-135.

[27] Warwick R.M., Clarke K.R., New 'biodiversity' measures reveal a decrease in taxonomic distinctness with increasing stress, Mar. Ecol. Prog. Ser. 129 (1995) 301-305.

[28] Wolff W.J., Duiven A.G., Duiven P., Esselink P., Gueye A., Meijboom A., Moerland G., Zegers J., Biomass of macrobenthic tidal flat fauna of the Banc d'Arguin, Mauritania, Hydrobiologia 258 (1993) 151-163.

[29] Wolff W.J., Gueye A., Meijboom A., Piersma T., Sall M.A., Distribution, biomass, recruitment and production of Anadara senilis (L.) (Mollusca; Bivalvia) on the Banc d'Arguin, Mauritania, Neth. J. Sea Res. 21 (1987) 243-253.

[30] Wolff W.J., Smit C.J., The Banc d'Arguin, Mauritania, as an environment for coastal birds, Ardea 78 (1990) 17-38.

[31] Zar J. H., Biostatistical Analysis. 3rd ed. Prentice-Hall, New Jersey, 1996, $920 \mathrm{p}$.

[32] Zwarts L., Numbers and distribution of coastal waders in Guinea-Bissau, Ardea 78 (1988) 193-208. 